\title{
Basic elements from a communicative strategic for the smoking
}

\section{control}

Efraín Sánchez González MD, Fé Fernández Hernández MD*

Faculty of Medical Science, University of Medical Science of Havana.

*Corresponding Author: Fé Fernández Hernández, Faculty of Medical Science, University of Medical Science of Havana.

Received date: March 16 2021; Accepted date: March 22, 2021 ; Published date: March 29,2021

Citation: Efraín S González, Fé F Hernández. (2021) Basic elements from a communicative strategic for the smoking control. Clinical Research and Clinical Trials. 3(2); DOI: 10.31579/2693-4779/030

Copyright: (C) 2021 Fé Fernández Hernández, This is an open access article distributed under the Creative Commons Attribution License, which permits unrestricted use, distribution, and reproduction in any medium, provided the original work is properly cited.

\section{Abstract}

Background: Societies where the public authorities had assumed a higher role respect to the smoking control had showed the benefits associated to the reduction from the smoking impact. For that it is necessary the designing of a communicative strategy focused on the public authorities to motive sufficiently them to be agreeing in the effective need about the smoking control.

Objective. To describe the main elements considering the designing a communicative strategy for the smoking control.

Materials and methods. Was made a descriptive research from the main elements considering the designing a communicative strategy for the smoking control. As teoric methods were utilized the analysis and synthesis, the inductive - deductive, the comparative and the historic - logic. As empiricmethod was utilized the bibliographic research.

Results. The strategy must be flexible and must be supported in a continued cycle process to make the necessaries adjustments agree to obtain the main objective. This condition suggests that the strategy maker must demonstrate a diverse and strong professional formation.

Conclusion. The designed communicative strategy for the smoking control must be capable to provide answers for the questions what communicate, why communicate, how to communicate and when communicate agree to the public authorities' characteristic.

Key words: communicative strategy;control;smoking

\section{Background}

Smoking is a risk factor close related with morbidity and mortality causes because of no - communicable illness $[1,2]$. These morbidity and mortality causes are the heavier around the world with specific variations agree to self-characteristic from each society [3, 4]. That's why the smoking control must be prioritized in all social contexts $[5,6]$.

Public authorities play a significant role in the smoking control because of their social responsibility [7, 8]. In lasts decades, societies where the public authorities had assumed a higher role respect to the smoking control had showed the benefits associated to the reduction from the smoking impact $[9,10]$.

For that these authorities may assume a similar position in their respective managing level, they need understand detailly the general and particular actual needs from the smoking control $[11,12]$. Then, it is necessary to develop a communicative strategy sufficiently efficient focused in the public authorities to obtain a general agreement about the real need about the smoking control $[13,14]$. Front of this situation it is necessary to describe the main elements considering the designing a communicative strategy for the smoking control, being this the main objective from this research.

\section{Materials and methods}

Was made a descriptive research from the main elements considering the designing a communicative strategy for the smoking control. As teoric methods were utilized the analysis and synthesis, the inductive deductive, the comparative and the historic - logic. As empiricmethod was utilized the bibliographic research.

\section{Results}

There are four elements that must define the communicative strategy for the smoking control. These are given by the following questions.

1) What communicate?

2) Why communicate?

3) How to communicate?

4) When communicate? 
The first question is determined by the general and specific characteristic from the public policies decider in a way that this group understand the real existence of the actual necessity from the smoking control over the population where the public authorities are manager.

In a decider group with high homogenization from the professional formation the projection from the strategy must be more thorough and specific in professional terms closest related with decider professional behavior. By this way should be more probable that public authorities understand the whole dimension of smoking impact and then the real need from the smoking control in the population managed by them.

In a more heterogeneous decider group the communicative strategy must be more general and diverse in their arguments keeping the objective to motive the public policies to adopt a public position favorable to the smoking control [15].

High heterogeneousness demand least specificness from the communicative strategy but include the real risk from don't value appropriately the real need about the smoking control in the population. For then, the communicative strategy must be highly thorough and diverse since the scientific point of view including all arguments needed to support the smoking control [16].

Usually the decider group is supported in specialist from several sciences. That's why the communicative strategy will be more trustable while more extensive would be [17].

For example, in an epidemiologist group the detailed description from the smoking impact over the morbidity and mortality is an initial argument that justifies the real need to adopt effective measures carrying to reduce the consumption of cigarettes and tobaccos. In an economist group the cost - benefit relation may be decisive. In this case it isn't sufficient with describe and/or quantify the high touchable social costs attributable to smoking. Also it is necessary to describe the same cost by the financial expression as social opportunity cost where be evident that the best scenario occurs in total absence of smoking and their consequences [18].

It is important to award the economic benefits related to the smoking existence. This don't means to assume a position favorable to smoking. Don't awards the whole dimension from these costs don't eliminate the smoking or their consequences. However, award it may to identify the economic arguments supporting the existence of smoking in the researched population and the main opportunities related to the smoking researching to raise more and new scientific arguments to a better description from the smoking impact [19].

Higher heterogeneousness and homogeneousness from deciders carries to develop from the scientific convergence from several sciences. For example, arguments since the Health Economy must be minimally sufficient for that economist and health deciders be agree in the real need from the smoking control in the population managed.

The question why communicates? Needs be satisfied by the extensive explication of the general and particular arguments showing the objective need about the smoking control. In this case is important to identify and characterize the smoking consequences over the whole population. For then the inclusion of several knowledge areas is close important to obtain the main objective from the communicative strategy [20].

Also it is important make a similar analysis about costs and benefits from the whole actions close associated to the effective smoking reduction agree to the communicative strategy. All arguments must be highly developed in a way that may show that in each possible scenario considered the no existence of the smoking is always better [21].

The question how communicates? Needs be satisfied with the general and specific ways to expose arguments carrying to public policies deciders assume a favorable position agree to the smoking control. In this case it is important that each decider understand and be agreeing with all arguments supporting it by their own professional formation. In this case the strategy must obtain a uniform and sufficient convergence from deciders about the real need about the smoking control in the population [22].

The question when communicate? Carries to take account the more indicate moment to communicate the arguments supporting the designed strategy. It must not be assumed a passive position waiting the simple occurrence of the wished moment. It is important the creation of communicative spaces where public policy deciders may assume an active position and establish a multidimensional interchangebetween deciders and strategy makers in away where decider's arguments be more explicated [23].

It is important understand that this process may not be considered lineally. The strategy must be flexible and must be supported in a continued cycle process to make the necessaries adjustments agree to obtain the main objective. This condition suggests that the strategy maker must demonstrate a diverse and strong professional formation [24].

\section{Conclusion}

The designed communicative strategy for the smoking control must be capable to provide answers for the questions what communicate, why communicate, how to communicate and when communicate agree to the public authorities' characteristic.

\section{References}

1. Arredondo A, Recaman AL, Pinzon C, Azar A (2018) Financial consequences from smoking-related diseases in middle-income countries: Evidence and lessons from Mexico. Int J Health Plann Mgmt 33: e454-e463.

2. Jiménez SY, Acuña MT (2016) Consumo de tabaco en costa rica, relación con múltiples patologías e importancia de la cesación de fumado. Revista Panamericana de Salud Pública 40: 204-212.

3. Barrenechea G, Cali S. Mortalidad atribuible al tabaquismo en Tucumán, Argentina 2001-2010. Medicina (B. Ai-res). 2016;76(5):287-93 [Internet] [citado 12 Jul 2019].

4. Cardentey García J. El tabaquismo: un flagelo nocivo para la humanidad. AMC [Internet]. 2016 Abr [citado 2020 Nov 21]; 20(2):114-7.

5. Fabelo Roche J, Lorenzo Vázquez EL, Iglesias Moré S, ÁlvarezMartínez E (2019). Impact of health warnings on cigarette packs on Cuban smokers. Health \& Society 9:306-313

6. Blanco, Adriana (2017) Diez años del Convenio Marco de la OMS para el Control del Tabaco: avances en las Américas. Salud Pública de México 59: 117-125.

7. Guindon GE, Paraje GR, Chaloupka FJ (2016) The impact of prices and taxes on the consumption of tobacco products in Latin America and the Caribbean. Pan Am J Pub Health 40: 272-284

8. Sánchez González E, Fernández Hernández F. (2017) El rol de las autoridades fiscales en el control del tabaquismo. Rev Ciencias Médicas [Internet]. Jun [citado 2019 Abr 25] ;21(3):62-67.

9. Reynales LM. (2012) El control del tabaco, estrategia esencial para reducir las enfermedades crónicas no transmisibles. Salud Pública de México.54(3): 323-31

10. CM, Muños JA, Sáenz de Miera-Juáre B, et al. Consumo de tabaco, mortalidad y política fiscal en México. (2013) Salud Pública Méx.55(Suppl 2):S276-S281 [In-ternet] [citado 12Dic2020].

11. Bardach, Ariel (2016) Carga de enfermedad por tabaquismo e impacto potencial del incremento de precios de cigarrillos en el 
Perú. Revista Peruana de Medicina Experimental y Salud Pública 33: 651-661

12. Guerrero-López CM, Reynales-Shigematsu LM, Jiménez-Ruiz JA, Karam-Araujo R, Maldonado-Cruz CA, Camacho-Solís R. (2012) Costos por ausentismo laboral atribuibles al consumo de tabaco en el Instituto Mexicano del Seguro Social y en México, 2006-2009. Salud Pública de México.54(3):233-41

13. Ortíz Agui María, Villar Carbajal Enit Ida, Llanos de Tarazona Marina Ivercia. (2020) Estrategia comunicativa orientada a la reducción de la exposición a factores de riesgo de arbovirosis. Medisur [Internet]. Abr [citado 2021 Feb 19];18(2):161-170.

14. FeoktistovaVictorava Liudmila, Ruenes Domech Caridad, García Bacallao Elsa F., Roblejo Balbuena Hilda, Morales Peralta Estela, Clark Feoktistova Yulia. (2020) Trastornos de la coagulación en pacientes cubanos con diagnóstico clínico de Enfermedad de Wilson. Medisur [Internet]. Abr [citado 2021 Feb 19] ; 18( 2 ): 171-176.

15. Udai Quispe-Juli Cender, Sánchez-Huamash Claudia María, Gozzer Ernesto. (2020) Redes sociales del Ministerio de Salud del Perú en la lucha contra la anemia: estudio cuali-cuantitativo de un video preventivo promocional. Rev. cuba. inf. cienc. salud [Internet]. [citado 2021 Feb 19] ; 31( 2 ): e1478.

16. Haithem Thabet Hassan, Quintana Ugando Maira, Rodríguez Méndez Leonardo. (2018) Promoción de salud y prevención de enfermedades de transmisión sexual en estudiantes universitarios. EDUMECENTRO [Internet]. [citado 2021 Feb 19] ; 10( 3 ):158-173.

17. Hernández Fonticiella Yenira, Aguiar Aguiar Giselvis, Valdés Valdés Anaisis. (2019) La exploración vivencial en la estimulación de la comunicación en trastornos del espectro de autismo. Rev. Mendive [Internet].Dic [citado 2021 Feb 19] ; 17( 4 ): 481-496.

18. Varona Pérez P, García Roche G, Willams Fogarty A, Britton J. (2015) Mortalidad por cáncer de pulmón y cardiopatía isquémica atribuible al tabaquismo pasivo en Cuba - 2011. Rev Cubana HigEpidemiol [Internet]. [citado 24 Dic 2020];53(2):[aprox. 0 p.].

19. Sánchez González E., Fernández Hernández F. (2020) Characterization of the Socioeconomic Inequity Attributable to Smoking. Journal of Quality in Health care \& Economics. 3(4).

20. Naranjo Hernández Ydalsys, Concepción Pacheco José Alejandro, Mirabal Requena Juan Carlos, Alvarez Escobar Belkis. (2020) A Nursing Strategy for the Self-Care of Older Adults with Diabetes Mellitus. Rev Cubana Med Gen Integr [Internet]. [citado 2021 Feb 19] ; 36( 3 ): e1188.

21. Serra Valdés Miguel, Serra Ruíz Melissa, Viera García Marleny. (2018) Las enfermedades crónicas no transmisibles: magnitud actual y tendencias futuras. Rev. Finlay [Internet]. [citado 2021 Feb 19] ; 8( 2 ): 140-148.

22. Grunfeld Baeza María Verónica, Martín Palomo Diego, Cecilia Arnaudo María, Celeste Arena María, D'Annuncio Valentina, Troccoli Milagros. (2018) Formar promotores de salud en contextos penitenciarios: una experiencia de la labor extensionista universitaria. EDUMECENTRO [Internet]. [citado 2021 Feb 19] ; 10( 1 ): 1-17.

23. de Rojas Gómez María Caridad, Pérez Cárdenas Adriana Lucía, Hernández Pérez María Esther. (2017)Talleres vivenciales: una modalidad pedagógica acertada para elevar la calidad de vida. EDUMECENTRO [Internet].[citado 2021 Feb 19] ; 9( 3 ): 300306.

24. Martínez Pérez Misleny. (2018) Modelo de promoción de salud dirigido a la población con riesgo de cardiopatía isquémica. Rev.Med.Electrón. [Internet]. Ago [citado 2021 Feb 19] ; 40( 4 ): 1070-1082. 